\title{
The Emilia-Romagna System for Start-Up Growth*
}

\author{
Sara Monesi ${ }^{* *}$, Sveva Ruggiero ${ }^{* * *}$, Lucie Sanchez ${ }^{* * * *}$
}

\begin{abstract}
EmiliaRomagnaStartup (ERSU) is one of the pillars of the Emilia-Romagna regional policy to promote innovative business creation. Launched in 2011, it represents nowadays one the most developed regional instruments at EU level to support start-up creation through information, orienteering, services provision and networking opportunities. The initiative is coordinated by ASTER, the regional Consortium for Innovation and Technology Transfer. Designed by ASTER Start-up Dept on the basis of an intensive benchmark activity to provide up-to-date services, today it is constantly improving the variety and the quality of its offer which is directed to start-ups and business projects, but also to the various regional actors that are part of its network.

Initiatives such as sector-focused acceleration programs (e.g. on Green or Creative sectors), opportunities to go global (through, for instance, the partnership with the Tech Venture Launch Program in Silicon Valley) and planning of new services through the participation in EU projects, represent the key added value ERSU can offer to its community of users.
\end{abstract}

Keywords: Start-Up Ecosystem; Public Policies; Innovation; Networking; Global Markets; Business Growth

\section{A Regional Integrated Policy to Support Start-Up Development}

The Emilia-Romagna is by tradition a fertile territory for the creation of new enterprises. Latest available data demonstrate the existence and the persistence, despite the economic crisis, of a vibrant and receptive ecosystem for creativity and innovation, which has produced significant results in terms of business creation.

In terms of numbers, Emilia-Romagna ranks $2^{\text {nd }}$ place in Italy with 579 start-ups, right after Lombardy.

The main features of the start-ups of the Emilia-Romagna region are the following: almost the totality is composed by micro-enterprises (an average

\footnotetext{
* Invited Article

** Start Up Department, Aster (sara.monesi@aster.it)

*** Start Up Department, Aster (sveva.ruggiero@aster.it)

**** Start Up Department, Aster (lucie.sanchez@aster.it)
}

Edited by: ISTEI - University of Milan-Bicocca

ISSN: $1593-0319$

Monesi, S., Ruggiero, S., \& Sanchez, L. (2015). The Emilia-Romagna System for Start-up Growth, Symphonya. Emerging Issues in Management (symphonya.unimib.it), 3, 40-47. 
turnover of 300-400,000 euro per year, with 3/4 employees) very few of them are participated by investors and industrial partners $(7 \%)$, the seed capital comes from members, family and friends and in $88 \%$ of cases is retained by them; half of the turnover is produced in the region and only $10 \%$ abroad $^{1}$.

One of the reasons of the presence of a significant number of new start-ups is the numerous programs supporting and accelerating business projects active in the region.

Programs such as SPINNER - the largest initiative launched by the EmiliaRomagna government to help people develop businesses and innovative project with high knowledge contents that has been running from 2001 to 2013 and was cofunded by the European Social Fund - and We Tech Off - one of the first Italian incubation actions dedicated to knowledge-based enterprises, running from 2003 to 2013 - marked an important step forward in terms of capacity building and allowed the regional ecosystem in acquiring expertise, tools and capacities to enable an entrepreneur (or a potential entrepreneur) access to resources, networks and opportunities.

Despite this encouraging performance, the Regional government is very committed to further develop its policies, since the size and the economic performance of the new enterprises (start-ups) is still too fable to be considered as a key driver for economic development and job creation. Nor their innovation potential has been fully exploited in terms of knowledge exploitation, open innovation strategies involving SMEs and corporate, and cross-sector development.

\section{Figure 1: Start-ups in Emilia-Romagna}

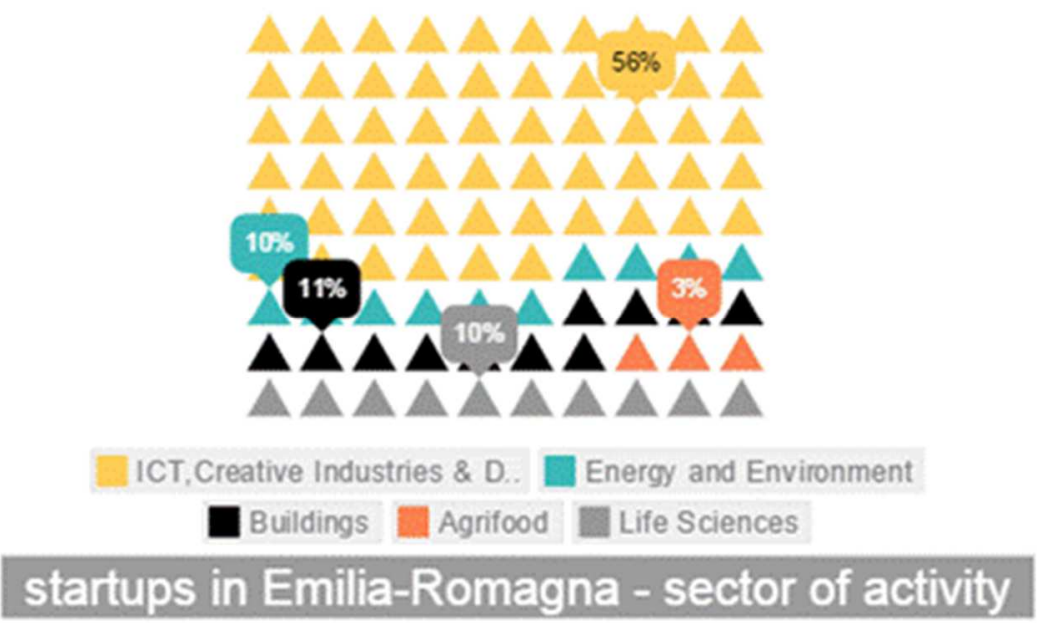

Today, the pillar for innovative business creation support is EmiliaRomagnaStartup (ERSU). ERSU aims at encouraging the creation of start- 
ups, by providing information, orienteering, specific advices and by networking ${ }^{1}$ all regional actors offering services and opportunities.

The network of actors that foster the creation and growth of innovative start-ups in Emilia-Romagna today consists of more than 60 subjects, public and private, and includes primarily Incubators, Innovation Centers and Chambers of Commerce, most of them providing support to start-ups active in all sectors. Services range from training on classical themes related to entrepreneurship to specialized consulting, business development and support for fund raising. Currently, the community that benefits from ERSU service is made by 354 start-ups, business projects and young companies.

Figure 2: Target, Opportunities and Service Basket
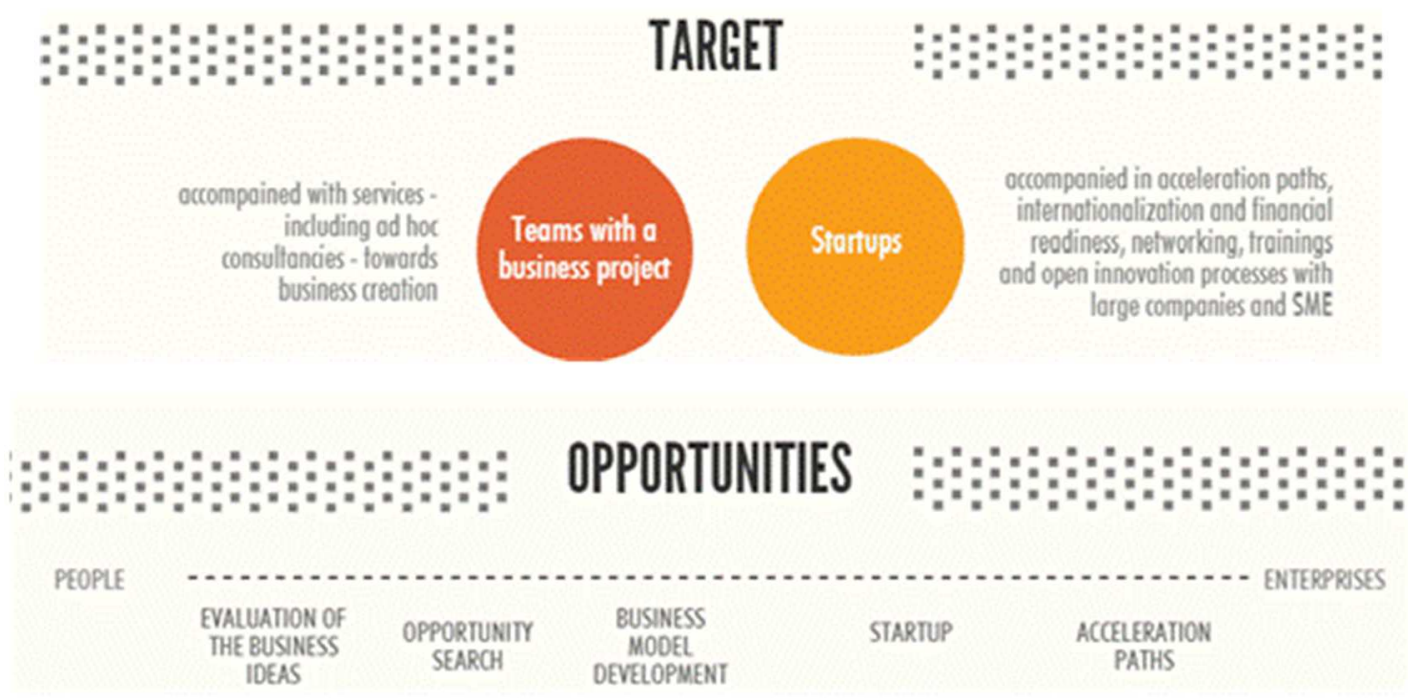


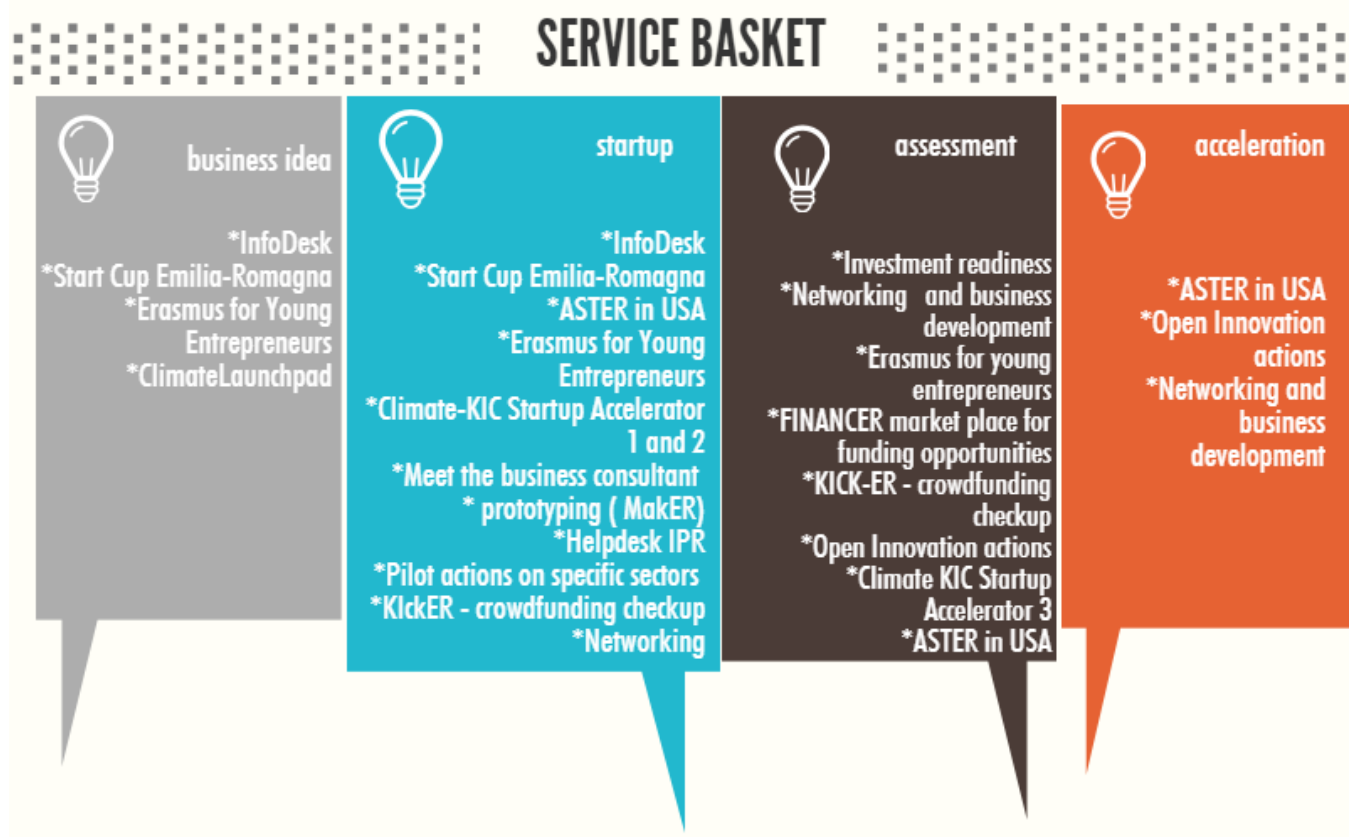

In addition to those services provided through EmiliaRomagnaStartup, ASTER Start-up Department has developed a full set of services to accompany new entrepreneurs over the whole development path: from business idea to growth acceleration. Services include for instance idea and business plan competitions (Start Cup Emilia-Romagna ${ }^{2}$ and ClimateLaunchpad ${ }^{3}$ ), services linked to accessing finance (FINANCER ${ }^{4}$ and $\mathrm{KICK}^{-E^{5}}{ }^{5}$ ), acceleration programmes (Climate-KIC Start-up Accelerator Italy), mobility programmes (delivery of Erasmus for young Entrepeneurs opportunities) and networking initiatives organized regularly for the start-up community to meet up.

\section{Who We Collaborate with and Who Mainly Inspires Us}

During the last 10 years of activity, we have often collaborated and been inspired - also thanks to the participation in European cooperation programs such as the $\mathrm{MED}^{6}$ - by French organizations and public initiatives. One of the best practices we appreciated most is the French law for innovation and research that made economically attractive for public researchers to start a company and the institution of a national network of business incubators to support the development of business ideas out of public research organizations.

There are 23 public research incubators for innovative start-ups in France, funded by the French Ministry of Higher Education and Research, regional authorities and other local administrations, that provide the same services and have similar work routines. There is for instance a certification process to ensure that services and organization respect defined quality standards. The presence of such organization in all regions enables entrepreneurs be supported the same way all around the country.

A very effective legal instrument adopted in France is the contract model Contrat d'Appui au Projet d'Entreprise (Contract to Support a Business Project) "CAPE"7 
that enables authorised incubators - the so called "couveuses d'entreprises" - to help entrepreneurs to start selling their products even before incorporating their company. CAPE is signed between the incubator and the entrepreneur to be, lasts 12 months and can be renewed twice. This type of contract has been promoted by the network 'Union des Couveuses d'entreprises" ${ }^{8}$ and is a perfect way to help entrepreneurs to be test their project feasibility for real but in a controlled environment.

Another France best practice that inspired us is the concept of Neoshop, an initiative launched by Laval Mayenne Technopole to help start-ups sell their products. Neoshop ${ }^{9}$ is both a real shop - opened in Laval in 2013 - and a service to support start-ups with sales and marketing. Neoshop enables start-ups: (1) Test the earliest sales, (2) Meet customers faster, (3) Strengthen marketing-mix enabling interactions with clients, (4) Bridge with distributors and (5) Promote ideas through the media while gaining public attention.

The last experience from France that can be mentioned is "La French Tech", a policy implemented by the French Ministry for Economy, Industry and Digital to support French technology start-ups start and grow. It promotes local ecosystems supporting tech start-ups through a fund to accelerate start-ups. La French Tech is also promoting start-ups presence in large international events and fairs: as an example, 190 French start-ups participated at the Consumer Electronic Snow in Las Vegas in 2016 with a huge visibility in the international press and among US investors.

We have also been collaborating with several organizations from Spain that have inspired new routines and joint services. For instance, we have been very much inspired by the services Barcelona Activa ${ }^{10}$ provides since early 2010s to foreign entrepreneurs interested in developing a branch in the city. Barcelona Landing Services is a one-stop-shop support service to accompany the Barcelona-based investment projects of companies and entrepreneurs living abroad. The portfolio of services includes: (1) Information and advice on procedures (legal, immigration, municipal permits and paperwork, etc.), (2) Company Incorporation, (3) Support with recruitment (3) Temporary offices and search of suitable premises. In addition, Barcelona Activa also provides training and consultancy on many business areas.

\section{Our Main Achievements in 2015}

With over 350 start-ups and 60 supporting organisations, around 1500 news published yearly, services provided on line and off line, ERSU is definitely the most developed platform for start-up support in Europe. We assisted 65 start-ups in various competence building paths, organized orienteering meetings (144) and provided networking opportunities (more than 50 start-ups accompanied in international events).

Concerning specific programs with sectors' focus, the main activities carried out are the Climate-KIC Start-up Accelerator for low carbon start-ups and ad-hoc paths for Cultural and Creative entrepreneurs growth. Those programs are developed with joint standard organization features in terms of timing and contents and specific 
services through the involvement of partners that can bring the sector knowledge and contacts. Regarding the scouting of new business ideas the most relevant initiative we coordinate is the Start Cup Emilia-Romagna, the main regional business plan competition between innovative entrepreneurial projects.

It currently involves more than 30 public and private partners (Municipalities, Incubators, Fab-lab, Innovation Centres) supporting the birth of new innovative enterprises and high knowledge content. In recent editions, the active involvement of the territories has brought the competition to reach significant numbers (over 100 projects collected) and a high quality standards of proposals.

The Start Cup is structured in a path with several steps, ranging from May to October, to accompany the participants to build their innovative company.

This year is particularly important for the Emilia-Romagna region because the National Innovation Award (the national final gathering the winners of all the regional Start Cup) will be hosted by the University of Modena and Reggio Emilia.

\section{What is Next}

In the next months, two important steps will be made: ASTER and EmiliaRomagnaStart-up will have new premises to host innovative start-ups in a key area in Bologna. The new incubator 'Le Serre dei Giardini Margherita' will host office space available for start-ups taking part in the acceleration programs run by ASTER. The premises are based in an area where the Municipality of Bologna, in collaboration with Region Emilia-Romagna and other partners ${ }^{11}$ is promoting the new hub for innovation and creativity in Bologna. There will be also offices dedicated to host foreign start-ups that arrive in Bologna through our mobility exchange programs.

The second step will be the definition and the testing of a sales support initiative for local start-ups based on the Neoshop model, above described. This initiative will be made possible by the EU project StartInnShop, an action cofounded by the European program Horizon 2020 that will help design a new service for start-up product commercialisation and will be developed by ASTER in cooperation with Laval Mayenne Technopole (Laval, France) and Rubicon Innovation Center (Cork, Ireland).

In 2016 the partnership with Technology Venture Launch Program ${ }^{12}$ (TVPLx) will be continued. ASTERinUSA is the full immersion program to accompany start-ups in Silicon Valley to approach to the US market and create a network of contacts to attract capitals and opportunities. The initiative is also aimed at learning good practices on collaborative processes between incubators and industries to implement open innovation processes.

\section{Conclusion}

EmiliaRomagnaStart-up platform represents one of the key tools for EmiliaRomagna region to support the start-up ecosystem at regional level, being the hub 
and the one-shop-stop to find out the most appropriate tools for business development.

It is also the instrument through which the regional ecosystem avoids duplications or overlapping, and collaborates to joint projects, as the regional business plan competition (the Start Cup), open innovation actions and internationalization paths.

ERSU regional platform allows to define an innovative offer of tools, services and models produced by the regional start-up ecosystem.

The next challenge is to match such offer with SMEs, Corporates and public administration offices needs to improve the regional economic framework.

\section{Bibliography}

Bellini, N. (2015). Smart Specialisation in Europe: Looking Beyond Regional Borders, Symphonya. Emerging Issues in Management (symphonya.unimib.it), 1, 22-29

http://dx.doi.org/10.4468/2015.1.03bellini

Brondoni, S.M. (2014). Global Capitalism and Sustainable Growth. From Global Products to Network Globalisation, Symphonya. Emerging Issues in Management (symphonya.unimib.it), 1, $10-31$

http://dx.doi.org/10.4468/2014.1.02brondoni

Brondoni, S.M. (2015). Global Networks, Outside-In Capabilities and Smart Innovation, Symphonya. Emerging Issues in Management (symphonya.unimib.it), 1, 6-21

http://dx.doi.org/10.4468/2015.1.02brondoni

Carayannis, E.G., \& Rakhmatullin, R. (2014). The quadruple/quintuple innovation helixes and smart specialisation strategies for sustainable and inclusive growth in Europe and beyond. Journal of the Knowledge Economy, 5(2), 212-239.

De la Mothe, J., \& Paquet, G. (Eds.). (2012). Local and regional systems of innovation (Vol. 14). Springer Science \& Business Media.

Gnecchi, F. (2009). Market-Driven Management, Market Space and Value Proposition, Symphonya. Emerging Issues in Management (symphonya.unimib.it), 2, 33-45 http://dx.doi.org/10.4468/2009.2.04gnecchi

Kourtit, K., \& Nijkamp, P. (2014). Applied regional growth and innovation models. R. J. Stimson (Ed.). Springer.

Mengel, S., \& Wouters, M. (2015). Financial planning and control in very small start-up companies: antecedents and effects on company performance. International Journal of Entrepreneurship and Small Business, 26(2), 191-216.

Riboldazzi, S. (2012). Market-Driven Management, Global Market and Prescribers. In S. Brondoni (a cura di), Managerial Economics and Global Corporations (111-124). Torino: Giappichelli.

Spigel, B. (2015). The relational organization of entrepreneurial ecosystems. Entrepreneurship Theory and Practice.

Tresca Roberta (2013). Global Business Networks and the Competitiveness of SMEs, Symphonya. Emerging Issues in Management (symphonya.unimib.it), 2, 67-78

http://dx.doi.org/10.4468/2013.2.05tresca

\section{Notes}


1 data processed following a survey among the start-ups registered on EmiliaRomagnaStart-up, carried out by Aster and the University of Bologna in October 2015

${ }^{2}$ http://www.startcupemiliaromagna.it/

${ }^{3}$ http://climatelaunchpad.org/

${ }^{4}$ http://financer.aster.it/

${ }^{5}$ http://www.kick-er.it/

${ }^{6} \mathrm{http}: / /$ www.programmemed.eu/en

${ }^{7}$ promoted by the Minister Claude Allègre that came into force in 1999

${ }^{7} \mathrm{https}$ ///www.service-public.fr/particuliers/vosdroits/F11299

$8 \mathrm{http}: / / \mathrm{www}$.uniondescouveuses.com/

${ }^{9}$ EBN (2016), Neoshop, the start-up shop, EBN Technical Note n.6, see: www.ebn.eu

${ }^{10} \mathrm{http}: / / \mathrm{www}$. barcelonactiva.cat/barcelonactiva/en/index.jsp

11 The Marino Golinelli Foundation, very active in the promotion of the culture of entrepreneurship among young people through initiatives like "Il Giardino delle Imprese" (The Entrepreneur's garden) and Kilowatt, a cooperative that runs a co-working space with innovative services, such as Kilowatt-baby , a kinder garden to host ko-workers' kids.

12 http://www.tvlp.co/ 